\title{
Factor V Leiden and Repeated Early Miscarriages
}

\author{
Fatima Zahra Gounain*, Nisrine Mamouni, Sanae Errharay, Chahrazed Bouchikhi, Abdelazez Banani \\ Obstetric Service of Gynaecology I, CHU HassanII, Fès, Morocco
}

\author{
DOI: $10.36348 /$ sijog.2020.v03i08.002 \\ | Received: 19.07.2020 | Accepted: 27.07.2020 | Published: 06.08.2020 \\ *Corresponding author: Fatima Zahra Gounain
}

Abstract

During pregnancy there is a physiological hypercoagulability which may be increased by genetic risk factors and / or acquired thrombosis. This increases the risk of thromboembolism and the risk of thrombosis in placental vessels and thus termination of pregnancy. Among genetic risk factors for thrombosis, factor V Leiden and mutated factor II are responsible for spontaneous miscarriages, which are essentially late. The rare deficits in antithrombin, protein $\mathrm{C}$ and protein $\mathrm{S}$ are also involved. Factor V Leiden is a thrombophilic condition that can lead to serious thromboembolic events and in pregnant women recurrent miscarriages. We report the case of a 36-year-old woman who presented 6 miscarriages that led to the diagnosis of thrombophilia by resistance to activated protein $\mathrm{C}$ and whose last 4 pregnancies were well followed by anticoagulant treatment with low molecular weight heparin aspirin.

Keywords: Factor V Leiden, repeated early miscarriages.

Copyright @ 2020: This is an open-access article distributed under the terms of the Creative Commons Attribution license which permits unrestricted use, distribution, and reproduction in any medium for non-commercial use (NonCommercial, or CC-BY-NC) provided the original author and source are credited.

\section{INTRODUCTION}

The resistance to activated protein $\mathrm{C}(\mathrm{RPCa})$ reflects in 90 to $95 \%$ of cases, a single mutation on the gene encoding factor $\mathrm{V}$ coagulation: it is called Factor $\mathrm{V}$ Leiden, the name of the city where the anomaly was discovered. This mutation leads to the replacement at position 506 of an arginine by glutamine (R506Q), which affects one of the Factor $\mathrm{V}$ cleavage sites by activated protein $\mathrm{C}(\mathrm{PCa})$, thereby inactivating its substrate less efficiently. In practice, the factor $\mathrm{V}$ Leiden loses its function as cofactor of the protein $\mathrm{C}$ system, that is to say of a coagulation inhibitor system; on the other hand, it retains its pro-coagulant properties. The other cases of CPP are acquired or related to one or more mutations [1]. Repetitive miscarriages, although described in the literature as a circumstance of constitutional thrombophilias that have been marked by the identification of two genetic risk factors for thromboembolic venous disease: the factor $\mathrm{V}$ Leiden and the G20210A mutation of prothrombin.) We report the case of a patient who presented 6 successive miscarriages widely explored before finally linking them to a factor 5 mutation of leiden [2].

\section{CASE REPORT}

This is a 36-year-old patient with positive blood group A who consulted for a problem of early repeated miscarriages (6 miscarriages before 9SA). Who presents as antecedents: operated for herniated disc in 2016; followed to the endocrinology department for nodular goitre under no treatment; with diabetes discovered in pre-conception period under diet alone. The patient consulted after 7 years of marriage for primary infertility, she had a succession of 6 pregnancies arrested in the first trimester documented. As part of the etiological assessment of this abortive disease, these explorations were performed: pelvic ultrasound with no particularities; Objective diagnostic hysteroscopy at exploration: cervical isthmic procession without peculiarities; normal uterine cavity, as well as the 2 ostuims seen; positive diabetes screening; a search for thrombophilia (Circulating anticoagulants: absent (lupus anticoagulant and diluted Russel viper venom time - screening), anti thrombin deficiency: absent, antinative DNA antibody: normal, anti-nuclear antibodies: normal, Protein S: absent, antiphospholipid antibody syndrome research by: anti-cardiolipin IgG and IgM antibodies: both <20 LPG-U / ml which are negative, search for anti-beta 2 glycoprotein 1- B 2GP1 IgM and $\mathrm{IgG}$ antibodies which are also $<20 \mathrm{U} / \mathrm{ml}$, search for 
hyperhomocysteinemia: absent at a level of 5.9umol / L which is normal compared to reference values $<13$, protein $\mathrm{C}$ deficiency: with resistance to protein $\mathrm{C}$ activated by ratio 1.92 which is pathological because the level is less than 2.17 so factor $\mathrm{V}$ is resistant to the proteolytic action of activated protein $\mathrm{C}$ as well as other normal hormonal balance sheets such as: testosterone dosage e, prolactin ...); a karyotype was requested to confirm the resistance to activated protein $\mathrm{C}$ returning in favor of the presence of the mutation c. 1601G> A (p.Arg534Gln) in exon 10 of the F5 gene.

A parental karyotype and hormonal assessment of the husband; hysterosalpingography; histopathological examinations of abortion products; a search for irregular agglutinins; an infectious assessment: vaginal sampling. All these reports were normal. Except 2 spermogram + spermoculture: at 3month intervals in the same laboratory in favor: hyperspermia with teratospermia essentially concerning head abnormalities with clear predominance of elongated and thinned heads compared to other anomalies that may be related to varicocele. The latter was removed by scrotal ultrasound with sterile culture.

It should be noted that 2 of these stopped pregnancies were carried out under Aspégic 100mg at a dose of one sachet per day and the last 4 under a combination of Aspégic-LMWH.

Note that our patient becomes pregnant naturally during 6 pregnancies without ovulation inducers or others.

\section{DISCUSSION}

Repeated spontaneous abortions (RAS) are defined as the occurrence of at least three embryo- fetal losses before 24 weeks of amenorrhea. They affect about 1 to $2 \%$ of fertile couples. The etiologies are multiple, however in $50 \%$ of the cases no cause is found [3].

Pregnancy is considered a state of hypercoagulability due to increased concentration of coagulation factors, decreased anticoagulants and fibrinolytic abilities. This condition predisposes to thromboses that may manifest as miscarriages. Gestational vascular complications may be related to maternal thrombophilic risk factors, whether they are acquired (anti-phospholipid syndrome) or hereditary (factor V Leiden, prothrombin mutation, methylene tetrahydrofolatereductase mutation [MLTHFR], deficiency in antithrombin and protein resistance $C$ and S) [4].
In early pregnancy (5-7 weeks), the trophoblastic invasion of the uterine spiral arteries leads to the appearance of vascular plugs (plugs) leading to the maintenance of the embryonic hypoxia necessary for its good evolution. Indeed, the embryo is at this stage devoid of the enzymatic defenses against free radicals of oxygen, and these plugs also fight against the maternal tension variations and allow the start of the embryonic heart and the extraction of the waste embryonic to the first intervillous lakes. The problem is that upstream of these plugs, the figured elements of blood stagnate and can lead to the formation of a thrombus if the woman has risk factors such as thrombophilia. When the plugs must begin to disappear (from 8 weeks), the thrombi remain and the pregnancy is interrupted by default of infusion of the embryo. Similarly, these thrombi can prevent the second trophoblastic colonization of the uterine vessels (myometrial spiral arteries) and lead to the occurrence of a vascular pathology of pregnancy (pre-eclampsia, intrauterine growth retardation of vascular origin, retroplacental hematoma, eclampsia and HELLP syndrome). The search for such pathologies during the interrogation of a woman with FCSR is therefore necessary [5].

La résistance à la protéine $\mathrm{C}$ activée (RPCA) a été découverte en 1993 par Dahlbäck qui démontra que chez 20 à $30 \%$ des patients qui présentent des thromboses veineuses récidivantes ou précoces, à caractère familial (thrombophilie clinique), la protéine $\mathrm{C}$ activée (PCA), anticoagulant naturel, allonge moins le temps de céphaline + activateur (TCA) que chez des sujets normaux. Cette anomalie, découverte par Bertina, est liée à une mutation dans le gène du facteur $\mathrm{V}$, qui entraîne un remplacement du résidu Arginine en position 506 en Glutamine (facteur V Leiden).

Donc La résistance à la protéine $\mathrm{C}$ activée (RPCA) constitue un facteur biologique majeur prédisposant aux manifestations thrombotiques veineuses. Elle est liée dans 85-90 \% des cas à une mutation au niveau du FV La transmission est autosomique dominante [6]. Le FV Leiden représente actuellement, par sa fréquence, la première cause de thrombophilie constitutionnelle. Le risque relatif de thrombose veineuse est multiplié par 5 à 10 chez les hétérozygotes et par 50 à 100 chez les homozygotes. La distribution de cette anomalie varie largement selon les zones géographiques (Table-1). Dans ces variations, il faut tenir compte de la taille des populations étudiées et des critères pour sélectionner les individus [7]. 
Table-1: Prévalence du FV Leiden [7]

\begin{tabular}{|c|c|c|c|c|}
\hline Pays & Individus & Hétérozygotes & Homozygotes & Fréquence \\
\hline \multicolumn{5}{|l|}{ Europe } \\
\hline Grèce & 187 & 24 & 1 & 7,9 \\
\hline Suède & 101 & 10 & 1 & 5,9 \\
\hline Allemagne & 1043 & 72 & 2 & 3,6 \\
\hline Royaume-Uni & 381 & 26 & & 3,4 \\
\hline Island & 96 & 3 & 0 & 2,6 \\
\hline Autriche & 104 & 5 & 1 & 2,4 \\
\hline Esapagne & 50 & 2 & 0 & 2 \\
\hline France & 51 & 2 & 0 & 2 \\
\hline Hollande & 474 & 14 & 0 & 1,5 \\
\hline Finanlde & 137 & 4 & 0 & 1,5 \\
\hline Italie & 1207 & 33 & 0 & 1,4 \\
\hline Groenland & 133 & 0 & 0 & 0 \\
\hline Basques & 28 & 0 & 0 & 0 \\
\hline \multicolumn{5}{|l|}{ Afrique } \\
\hline Sénégal & 96 & 0 & 0 & 0 \\
\hline Zambie & 95 & 0 & 0 & 0 \\
\hline Kenya & 308 & 0 & 0 & 0 \\
\hline \multicolumn{5}{|c|}{ Amérique du Nord } \\
\hline Blancs & 704 & 42 & 0 & 3 \\
\hline Noirs & 307 & 4 & 0 & 0,65 \\
\hline Ashkénazes & 91 & 2 & 0 & 1,1 \\
\hline Jamaicains & 91 & 0 & 0 & 0 \\
\hline \multicolumn{5}{|c|}{ Amérique du Sud } \\
\hline Indiens du & 19 & 0 & 0 & 0 \\
\hline Indiens du & 83 & 0 & 0 & 0 \\
\hline Noirs du & 137 & 1 & 0 & 0,4 \\
\hline \multicolumn{5}{|c|}{ Asie et Moyen-Orient } \\
\hline Russie & 156 & 10 & 2 & 4,5 \\
\hline Inde & 203 & 5 & 0 & 1,2 \\
\hline Arabie & 255 & 5 & 0 & 0,98 \\
\hline Chine & 254 & 0 & 0 & 0 \\
\hline Indonésie & 105 & 0 & 0 & 0 \\
\hline Japon & 270 & 0 & 0 & 0 \\
\hline Corée & 93 & 0 & 0 & 0 \\
\hline Mongolie & 36 & 0 & 0 & 0 \\
\hline Sri Lanka & 47 & 0 & 0 & 0 \\
\hline \multicolumn{5}{|l|}{ Océanie } \\
\hline Australie & 73 & 0 & 0 & 0 \\
\hline Australie & 126 & 5 & 0 & 2 \\
\hline Papouasie- & 95 & 0 & 0 & 0 \\
\hline
\end{tabular}

It is the most common constitutional cause of thrombophilia: its prevalence is between $1 \%$ and $3 \%$ in the European population and is rare in Africa and Asia [8-10].

The clinical manifestations are varied, ranging from deep vein thrombosis to classical localizations (thrombosis of the cerebral vein) or much less common (thrombosis of the portal vein, Budd-Chiari syndrome, mesenteric vein thrombosis) and embolism. pulmonary $[11,12]$. The role of the FPCA linked to factor $\mathrm{V}$ Leiden mutation in the occurrence of FCSR-type obstetric accidents is still controversial. Balasch [13] found no association between the presence of the
Leiden mutation and the occurrence of early FCSR. Grandone [14] observed a slightly higher but nonsignificant frequency of the mutation during first trimester fetal losses, whereas the difference was significant for second and third trimester accidents. Meinardi [15] evaluates the risk on a cohort of 228 women carriers of the mutation and 121 without this abnormality, and finds a higher frequency of FCSR occurring before the 20th SA in women with the mutation compared to the control population $(29.4 \%$ vs. $17.4 \%$ ). Homozygosity for mutation causes more accidents than heterozygosity. The risk of recurrence is also greater in the homo- and heterozygous population compared to the control population $(10.1 \%$ vs. $4.1 \%)$. 
venous thromboembolism prophylaxis in pregnant women with no previous history of VTE presenting with SAPL or antithrombin deficiency, or homozygosity for Leiden Factor V or prothrombin mutation, or composite heterozygosity for the latter two mutations. Various recommendations suggest preventive anticoagulation with low molecular weight heparin (eg, enoxaparin $40 \mathrm{mg} / \mathrm{d}$ ) during pregnancy and / or six weeks postpartum $[16,17]$.

\section{CONCLUSION}

While $90 \%$ of the first FCS are due to a chromosomal abnormality of the fetus [18], occurring mainly during the 1 st trimester, more than $50 \%$ of the repeated FSCs are due to a bleeding disorder. Lupus anticoagulant and antiphospholipid antibodies are the most incriminated in the occurrence of FCS. Among the genetic risk factors, factor V Leiden and the 20210A allele of factor II, common in the population, are now incriminated as well as rare deficits in AT, PC and PS. Terminations occur at any time during pregnancy, but more often late. Further studies are needed to confirm the risk of resistance to activated protein $\mathrm{C}$ and PAI-1 promoter polymorphisms [19].

At the physiological systemic hypercoagulability of pregnancy, possibly augmented by other risk factors, it is necessary to add a potential local hypercoagulability, due to an excessive production of phospholipid microparticles whose study is in full swing.

A biological assessment of the biological risk factors for thrombosis is recommended for women who have had at least 3 consecutive FCS during the 1st trimester, 2 FCS or more during the 2 nd trimester, 1 death in utero or more during the 3 rd quarter [20].

Anticoagulant therapy, most commonly low molecular weight heparin, for the prevention of CRF has been evaluated in a large number of studies, particularly in women with antiphospholipid or factor $\mathrm{V}$ Leiden syndrome. factor II 20210A or antithrombin deficiency, protein $\mathrm{C}$ or protein $\mathrm{S}$. In SAPL, the combination of aspirin and LMWH has been shown to be effective and significantly reduces the risk of pregnancy termination. Favorable results, up to $86 \%$ success has been achieved, but other prospective randomized studies are needed to better define the therapeutic modalitie [21].

\section{REFERENCES}

1. Morange, P. E., \& Facteur, V. L. (2003). Encycl Med Biol, Elsevier, Paris.

2. Rey, E., Kahn, S. R., David, M., \& Shrier, I. (2003). Thrombophilic disorders and fetal loss: a meta-analysis. The Lancet, 361(9361), 901-908.

3. Jauniaux, E., Farquharson, R. G., Christiansen, O. B., \& Exalto, N. (2006). Evidence-based guidelines for the investigation and medical treatment of recurrent miscarriage. Human reproduction, 21(9), 2216-2222.

4. Merviel, P., Carbillon, L., Challier, J. C., Rabreau, M., Beaufils, M., \& Uzan, S. (2004). Pathophysiology of preeclampsia: links with implantation disorders. European Journal of Obstetrics \& Gynecology and Reproductive Biology, 115(2), 134-147.

5. Bertina, R. M., Koeleman, B. P., Koster, T., Rosendaal, F. R., Dirven, R. J., de Ronde, H., ... \& Reitsma, P. H. (1994). Mutation in blood coagulation factor $\mathrm{V}$ associated with resistance to activated protein C. Nature, 369(6475), 64-67.

6. Manuel du Résident. (2009). Hématologie II, Edition tsunami. Exclusivité, 13-000-M- 56.

7. Ford, H. B., \& Schust, D. J. (2009). Recurrent pregnancy loss: etiology, diagnosis, and therapy. Reviews in obstetrics and gynecology, 2(2), 76-83.

8. Brenner, B. (2004). Haemostatic changes in pregnancy. Thrombosis research, 114(5-6), 409. 414.

9. Gris, J. C., Quéré, I., Monpeyrou, F., Mercier, E., Ripart-Neveu, S., Tailland, M. L., ... \& Marès, P. (1999). Case-control study of the frequency of thrombophilic disorders in couples with late foetal loss and no thrombotic antecedent. Thrombosis and haemostasis, 81(06), 891-899.

10. Bretelle, F., Sabatier, F., Desprez, D., Camoin, L., Grunebaum, L., Combes, V., ... \& Dignat-George, F. (2003). Circulating microparticles: a marker of procoagulant state in normal pregnancy and pregnancy complicated by preeclampsia or intrauterine growth restriction. Thrombosis and haemostasis, 89(03), 486-492.

11. Martinelli, I., De Stefano, V., Taioli, E., Paciaroni, K., Rossi, E., \& Pier, M. M. (2002). Inherited thrombophilia and first venous thromboembolism during pregnancy and puerperium. Thrombosis and haemostasis, 87(05), 791-795.

12. Balasch, J., Reverter, J. C., Fábregues, F., Tassies, D., Rafel, M., Creus, M., \& Vanrell, J. A. (1997). First-trimester repeated abortion is not associated with activated protein $\mathrm{C}$ resistance. Human reproduction (Oxford, England), 12(5), 10941097.

13. Grandone, E., Margaglione, M., Colaizzo, D., d'Addedda, M., Cappucci, G., Vecchione, G., ... \& Di Minno, G. (1997). Factor V Leiden is associated with repeated and recurrent unexplained fetal losses. Thrombosis and haemostasis, 77(05), 822-824.

14. Meinardi, J. R., Middeldorp, S., de Kam, P. J., Koopman, M. M., van Pampus, E. C., Hamulyák, K., ... \& van der Meer, J. (1999). Increased risk for fetal loss in carriers of the factor $\mathrm{V}$ Leiden mutation. Annals of internal medicine, 130(9), 736-739.

15. Simioni, P. (2006). Who should be tested for 
thrombophilia?. Current

hematology, 13(5), 337-343.

opinion

in

16. Lim, W., Eikelboom, J. W., \& Ginsberg, J. S. (2007). Inherited thrombophilia and pregnancy associated venous thromboembolism. Bmj, 334(7607), 1318-1321.

17. Alhenc-Gelas, M., \& Aiach, M. (2007). Anomalies constitutionnelles de la coagulation prédisposant à la thrombose. EMC-Hématologie. Jan, 2(2), 1-18.

18. Vossen, C. Y., Preston, F. E., Conard, J., Fontcuberta, J., Makris, M., Van Der Meer, F. J. M., ... \& Svensson, P. (2004). Hereditary thrombophilia and fetal loss: a prospective follow- up study. Journal of Thrombosis and Haemostasis, 2(4), 592-596.

19. Kujovich, J. L. (2004). Thrombophilia and pregnancy complications. American journal of obstetrics and gynecology, 191(2), 412-424.

20. Pabinger, I., \& Vormittag, R. (2005). Thrombophilia and pregnancy outcomes. Journal of Thrombosis and Haemostasis, 3(8), 1603-1610.

21. Gris, J. C., Mercier, E., Quéré, I., LavigneLissalde, G., Cochery-Nouvellon, E., Hoffet, M., ... \& Mares, P. (2004). Low-molecular-weight heparin versus low-dose aspirin in women with one fetal loss and a constitutional thrombophilic disorder. Blood, 103(10), 3695-3699. 